\title{
Challenges for Indonesia Zero Hunger Agenda in the Context of COVID-19 Pandemic
}

\author{
Bunga Astria Paramashanti
}

Department of Nutrition, Faculty of Health Sciences, Universitas Alma Ata, Yogyakarta, Indonesia

\begin{abstract}
The rapid spread of COVID-19 has not only threatened the lives of the infected people but also socially and economically affected a broader community. The pandemic has also challenged the second goal of the 17 Sustainable Development Goals (SDGs) to eliminate all the forms of hunger by 2030. The most disadvantaged people may have a greater risk of having malnutrition and poor health as they cannot access a diet that is safe, nutritious, affordable, and sustainable. At this moment, saving lives by focusing on the health-care system should not be the only priority; the emphasis should be made in other essential aspects, including agri-food sector, in order not to cause any additional burden of hunger, malnutrition, and overall health.
\end{abstract}

Keywords: COVID-19, Indonesia, novel coronavirus, Sustainable Development Goals, Zero Hunger

\section{Introduction}

Since the first case of severe acute respiratory syndrome coronavirus 2 (SARS-CoV-2) was reported in December 2019 in Wuhan, Hubei Province, China, ${ }^{1}$ the coronavirus disease 2019 (COVID-19) has spread to at least 212 countries and territories worldwide. As of May 4, 2020, when this manuscript was being written, there were 11,587 people diagnosed with COVID-19 and 864 deaths caused by the virus confirmed in Indonesia. Not only the infected people, but a wider society has also been socially and economically affected.

Indonesia's economic growth was advancing rapidly over the last decade with the gross domestic product (GDP) remained approximately at 5\%. Nonetheless, the benefits have not been equally distributed among the Indonesian population. The recent report revealed that the GDP in the first quarter of 2020 slowed to around $3 \%$. At this point, around 22 million Indonesians had already experienced hunger in 2016-2018. ${ }^{2}$ Things could get worse before getting better.

To cut the virus transmission and lessen its impacts, the Indonesian Government has continuously called for "stay at home" to all the citizens. Moreover, some regions have implemented large-scale social restriction which requires the closing of schools, offices, and public spaces, reduction in the public transport capacity, and restriction

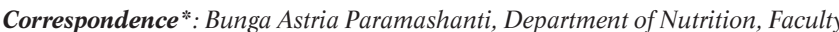
of Health Sciences, Universitas Alma Ata, Brawijaya Street No. 99, Yogyakarta, Indonesia 55183, E-mail: bunga@almaata.ac.id, Phone: +62 821-3193-1623 in public activities, such as religious and cultural events. As one of the essential services, the food, and beverage sector is still allowed to run in the aftermath of the COVID-19 pandemic. ${ }^{3}$ However, the Indonesian Minister of Agriculture, Syahrul Yasin Limpo, admitted that the novel coronavirus pandemic has disrupted food supply chains, resulting in food price volatility and decreased purchasing power at the national and the global levels. ${ }^{4}$ A distorting food environment means that there will be a change in dietary practices that may affect nutrition and health status.

The United Nations Development Programme (UNDP) has stated the global health and economic crises raising as the impact of COVID-19 pandemic. The dual crises may continue to overload policy and health-care systems. For this issue, the political response will decide the extent of the virus as well as the continuation of achieving Sustainable Development Goals (SDGs). ${ }^{5}$ Undoubtedly, the crisis demands a collective response.

\section{Results and Discussion}

The second goal of SDGs aims to "end hunger, achieve food security, and improve nutrition and promote sustainable agriculture”. Working for Zero Hunger means ensuring that all people, particularly children, have adequate and nutritious food throughout 
the year for a healthy life. While undernutrition has declined by nearly half in many countries due to rapid economic growth and rising agricultural productivity, it is unfortunate that some still face malnutrition and starvation. ${ }^{6}$ In this current situation, the question is, what consequences does the COVID-19 have on the SDGs?.

Firstly, the pandemic may affect food security by interrupting the food system. We should look again at the Indonesian Government's responses to limit transnational and national movements to cut the growing transmission of the COVID-19. The regulations sure have struck economic activities heavily in several ways, including on food value chains. Similarly but differently, the pandemic crisis has affected food demand, production, distribution and storage, processing, and marketing for both the low- and the high-income population. ${ }^{7}$ Even though there is no direct prohibition on the food and beverage sector in Indonesia, there has been a change on the way of food being produced and consumed.

Indonesian agriculture is dominated by smallholder farmers. Ironically, as food producers, farmers are highly affected by the threat of a food security crisis due to poverty. As a result, they are unable to buy seeds and renew their crops. ${ }^{8}$ Yet, we should not worry about the staple food supply in the next three to four months. Rice and corn stocks from March to May 2020 were 15.9 million tons and 10.3 million tons, respectively, compared to the estimated need of the population, each at 7.6 and 6.0 million tons. ${ }^{9}$ Then, what will happen after May?.

During the focus group discussion on "Effectiveness Strategies for Implementing Economic Stimulus Impacts of COVID-19", the President Director of PT Perkebunan Nusantara VIII said that grain production will fall by $50 \%$. Based on the field observation, rice production dropped from 5-6 tons per hectare to 3 - 3.5 tons per hectare. Some regions have now increased the rice market price such as in Lembang with the rice price at IDR 12,000 per $\mathrm{kg}$, exceeding the average price of IDR 8,500 per kg. ${ }^{10}$ At the same time, Indonesia is still heavily relying on the imported source of animal protein, such as beef and broiler. By the end of May, the estimated commodity of broiler is only 219,000 thousand tons, while beef is minus 19,000 thousand tons. ${ }^{9}$ A food import strategy may be an alternative to maintain price stability. Still, other countries may also struggle with their food security and put restrictions on their exports.

Consumers' demands for various food products has been reduced due to human movement restriction, high price volatility, and reduced purchasing power. If we look back in 2019, the hunger level in Indonesia was categorized as serious, ${ }^{11}$ and the food security performance ranked the $62^{\text {nd }}$ among 113 countries, ${ }^{12}$ while the poor population was at $9.22 \% .13$ The Indonesian Minister of Finance, Sri Mulyani Indrawati, said that the pandemic may place the poverty rate into the double-digit as in 2011. ${ }^{14}$ What could be worse than dying from the virus or starving to death?

Secondly, hunger can happen when the community is faced with severe food insecurity. In this state, food cannot be obtained for a long period, either geographically or financially. For those who still manage to access food, though perhaps not always, moderate food insecurity may cause them to risk food quality and adequacy. Worse still, we must not forget the most affected people already in food shortage, or children relying on food supplementation programs, or the lowincome informal workers. ${ }^{14}$ Too many people are not getting access to safe, nutritious, affordable, and sustainable diets. Unfortunately, there are many data gaps to draw up a further conclusion on this pandemic effect, however, we cannot ignore the rising risks of malnutrition and poor health.

Thirdly, children are the most vulnerable group affected by hunger. ${ }^{11}$ Of the Zero Hunger targets, it is globally agreed to reduce wasting and stunting among the under-five. ${ }^{6}$ As a consequence of the COVID-19 pandemic, recent food shortage may cause children at risk of having acute malnutrition due to substantial weight loss or wasting. Given its chronic nature, the risk of stunting should not be left behind. Stunted growth may also occur among children who are already in a state of long-standing food scarcity.

One of three under-five children in Indonesia has already suffered from stunted growth in 2018,15 indicating chronic undernutrition. There was only a $1.3 \%$ annual decrease since 2013.16 The progress was not even close to the global and national targets which require $3.9 \%$ and $2.8 \%$ yearly reduction, respectively. With this emergency happening, we will be far further from the target.

Micronutrient deficiency may also arise. Hidden hunger affects both children and women. The most common form is iron deficiency anemia with its prevalence around $39 \%$ among children and $49 \%$ among mothers. ${ }^{15}$ In children, iron deficiency may reduce learning ability and school performance, whereas women are at risk for mortality during or after delivery. ${ }^{17}$

Last but not least, the burden of malnutrition can be extended beyond hunger to overweight and obesity. The way crop harvesting on the farm has been changed due to globalization and urbanization which causes the highlyprocessed food displayed in the supermarket. ${ }^{18}$ While physical distancing becomes common, consumers prioritize purchasing food which is durable, affordable, and easily accessed and prepared. This calling may invite an increased consumption of ultra-processed food with 
high levels of sugar, fat, salt and energy, but low in fiber. Additionally, staying at home may also increase the sedentary lifestyle and reduce physical movement. Both excessive energy intake and low physical activity are the main drivers of overweight and obesity. ${ }^{19}$

There will be no healthy lives without healthy eating, and healthy eating cannot exist without sustainable agriculture. ${ }^{20,21}$ Nevertheless, health and agriculture agencies have little cooperation and are often steered by distinctive and conflicting priorities. ${ }^{20}$ Also, the lack of data underlines the importance of effective monitoring and evaluation systems in each sector, followed by data sharing between sectors. The goal is early detection and immediate response with emphasis on cost-effectiveness and cross-sector collaboration.

\section{Conclusion}

COVID-19 pandemic could reverse Indonesia's progress towards the second goal of 17 SDGs by 2030 . The unprecedented crisis may affect the Zero Hunger agenda in Indonesia which include food insecurity, hunger, and malnutrition - especially childhood stunting. The policymakers are urged to assist most vulnerable groups that are not only the infected patients or their family members, but also people who are food-deprived and malnourished. Saving lives is a priority; however, attention and efforts must consider other aspects such as food and agriculture, economy, social protection, and education without adding the burden of another humanitarian catastrophe.

\section{Abbreviations}

SDGs: Sustainable Development Goals; SARS-CoV-2: Severe Acute Respiratory Syndrome Coronavirus 2; COVID-19: Coronavirus Disease 2019; GDP: Gross Domestic Product; UNDP: United Nations Development Programme.

\section{Ethics Approval and Consent to Participate \\ Not Applicable}

\section{Competing Interest}

No potential conflict of interest was reported by the author.

\section{Availability of Data and Materials \\ Not Applicable}

\section{Authors' Contribution}

Bunga Astria Paramashanti contributed substantially to the conception, writing, and revising of the manuscript.

\section{Acknowledgment \\ Not Applicable}

\section{References}

1. Wu F, Zhao S, Yu B, Chen Y-M, Wang W, Song Z-G, et al. A new coronavirus associated with human respiratory disease in China. Nature. 2020; 579 (7798): 265-9.

2. Asian Development Bank. Policies to support investment requirements of Indonesia's food and agriculture development during 2020-2045. Manila: Asian Development Bank, IFPRI and Kementerian PPN / Bappenas; 2019.

3. Ministry of Health of Indonesia. Peraturan Menteri Kesehatan Republik Indonesia Nomor 9 Tahun 2020 tentang Pedoman Pembatasan Sosial Berskala Besar dalam Rangka Percepatan Penanganan Corona Virus Disease 2019 (COVID-19); 2020.

4. Ministry of Agriculture of Indonesia. Pertemuan menteri G20, Indonesia tekankan penguatan sistem pangan menghadapi COVID-19; 2020.

5. United Nations Development Programme. The social and economic impact of COVID-19 in the Asia-Pacific region. Position note prepared by UNDP Regional Bureau for Asia and The Pacific. Bangkok: United Nations Development Programme; 2020.

6. United Nations Development Programme. Goal 2: zero hunger; 2020.

7. Haddad L, Fanzo J, Godfrey S, Hawkes C, Morris S, Neufeld LM. The COVID-19 crisis and food systems: addressing threats, creating opportunities. ed. 23 March 2020. London: Global Alliance for Improved Nutrition (GAIN).

8. Pusat Penelitian Kependudukan LIPI. Ketahanan pangan dan ironi petani di tengah pandemi COVID-19. Jakarta: Lembaga Ilmu Pengetahuan Indonesia; 2020.

9. Hirawan FB, Verselita AA. Kebijakan pangan di masa pandemi COVID-19. Jakarta: CSIS Indonesia; 2020.

10. Thomas VF. Pandemi corona: Indonesia bisa kekurangan beras dan bahan pangan. tirto.id; 2020.

11. Global Hunger Index. Global hunger index 2019: Indonesia. ed. October 2019; 2019.

12. Global Food Security Index. Global food security index: ranking and trends; 2019.

13. Badan Pusat Statistik Indonesia. Persentase penduduk miskin September 2019 turun menjadi 9,22 persen. Jakarta: Statistical Bureau of Indonesia; 2020.

14. Food and Agriculture Organization. The state of food security and nutrition in the world 2019. Safeguarding agaist economic slowdowns and downturns. Rome: Food and Agriculture Organization (FAO); 2019.

15. National Institute of Health and Research Development. Laporan nasional riskesdas 2018. Jakarta: National Institute of Health and Research Development (Balitbangkes); 2019.

16. National Institute of Health and Research Development. Laporan Nasional Riskesdas 2013. Jakarta: National Institute of Health and Research Development (Balitbangkes); 2013.

17. United Nations Children's Fund. Key asks for 2020 SDG voluntary national reviews: zero hunger. New York: UNICEF; 2020.

18. United Nations Children's Fund. The state of the world's children 2019: children, food and nutrition: growing well in a changing world. New York: UNICEF; 2019.

19. Romieu I, Dossus L, Barquera S, Blottière HM, Franks PW, Gunter 
Paramashanti, Challenge for Indonesia Zero Hunger Agenda in the Context of COVID-19 Pandemic

M, et al. Energy balance and obesity: what are the main drivers?. CCC-Cancer Causes \& Control. 2017; 28 (3): 247-58.

20. Nugent R. Bringing agriculture to the table: how agriculture and food can play a role in preventing chronic disease. Chicago, USA: The Chicago Council on Global Affairs; 2012.
21. Lartey A, Meerman J, Wijesinha-Bettoni R. Why food system transformation is essential and how nutrition scientists can contribute. Annals of Nutrition and Metabolism. 2018; 72 (3): 193-201. 